\title{
Different soil moisture control of net methane oxidation and production in organic upland and wet forest soils of the Pacific coastal rainforest in Canada
}

\begin{tabular}{|r|l|}
\hline Journal: & Canadian Journal of Forest Research \\
\hline Manuscript ID & cjfr-2016-0390.R1 \\
\hline Danuscript Type: & Article \\
\hline Complete List of Authors: & $\begin{array}{l}\text { Christiansen, Jesper; Kobenhavns Universitet Det Natur- og } \\
\text { Biovidenskabelige Fakultet, Department of Geoscience and Natural } \\
\text { Resource Management } \\
\text { Levy-Booth, David; The University of British Columbia, Department of } \\
\text { Microbiology and Immunology } \\
\text { Prescott, Cindy; The University of British Columbia } \\
\text { Grayston, Sue; University of British Columbia, }\end{array}$ \\
\hline Keyword: & $\begin{array}{l}\text { gene abundance, methane, microbial community, soil hydrology, } \\
\text { temperate rainforest }\end{array}$ \\
\hline Please Select from this Special \\
Issues list if applicable:
\end{tabular}

SCHOLARONE ${ }^{\text {m }}$

Manuscripts 
1 Title: Different soil moisture control of net methane oxidation and production in organic upland and

2 wet forest soils of the Pacific coastal rainforest in Canada

3 Authors:

$4 \quad$ Jesper Riis Christiansen ${ }^{1,3}$, David Levy-Booth ${ }^{2}$, Cindy E Prescott ${ }^{1}$ and Sue J Grayston ${ }^{1}$

$5 \quad{ }^{1}$ Department of Forest and Conservation Sciences, University of British Columbia, Main Mall 2424,

$6 \quad$ V6T 1 Z4 Vancouver, Canada (emails: Cindy E. Prescott - cindy.prescott@ubc.ca; Sue Grayston -

7 sue.grayston@ubc.ca)

$8 \quad{ }^{2}$ Department of Microbiology and Immonology, University of British Columbia, $1365-2350$

9 Health Sciences Mall, Vancouver, British Columbia Canada V6T 1 Z3 (DLB -

10 dlevybooth@gmail.com)

$11{ }^{3}$ Department of Geoscience and Natural resource Management, University of Copenhagen,

12 Rolighedsvej 23, DK-1958 Frederiksberg C, Denmark

13 *Corresponding author: jrc@ign.ku.dk, telephone: +4535336942 , fax: +4535331517 


\section{Abstract}

In a changing climate, understanding how soil hydrology impacts greenhouse-gas dynamics will be important for the future management of the soils in the forests on the Canadian Pacific west coast. In a laboratory study the impact of soil hydrology on potential net methane $\left(\mathrm{CH}_{4}\right)$ exchange rates and the abundance of methanotrophs $\left(\mathrm{CH}_{4}\right.$ oxidation) and methanogens $\left(\mathrm{CH}_{4}\right.$ production $)$ in upland and water-saturated wet soils were investigated.

Methane oxidation and production rates were highest in the wet soils which corresponded to higher numbers of methanotrophs and methanogens indicating a link between the microbial abundance and $\mathrm{CH}_{4}$ exchange rates. Also, $\mathrm{CH}_{4}$ production was induced in the upland soils indicating the presence of methanogens. The optimum soil moisture content for $\mathrm{CH}_{4}$ oxidation was highest in upland soils and the wet soils sustained higher $\mathrm{CH}_{4}$ oxidation rates over a broader range of soil moisture. These results underline the importance of the soil hydrological controls of $\mathrm{CH}_{4}$ oxidation in contrasting soils and forest type, which deserves further attention in field based studies.

Keywords: gene abundance, methane, microbial community, soil hydrology, temperate rainforest 


\section{Introduction}

The Pacific coastal temperate rainforest of North America is part of one of the most productive terrestrial biomes on the northern hemisphere (Waring and Franklin, 1979). The combination of high precipitation, relatively low soil temperatures and mountainous topography throughout the Pacific temperate rainforest has resulted in a complex landscape mosaic of productive upland forests and wetlands. Well-drained upland forest soils throughout this region can be sinks of atmospheric $\mathrm{CH}_{4}$ (Basiliko et al., 2009; Christiansen et al., 2016) and sources of $\mathrm{CO}_{2}$ (Jassal et al., 2005). However, in wetter areas substantial accumulations of soil organic carbon occur as thick forest floors and peat (Banner et al., 2005). This creates the potential for methane $\left(\mathrm{CH}_{4}\right)$ emissions in wetter parts of the landscape in the Pacific temperate rain forest. In a changing climate, the changes in forest hydrology will influence soil moisture dynamics and decomposition of organic material, with currently unknown impacts on $\mathrm{CH}_{4}$ exchange between the soil and the atmosphere. Understanding the implications of changes in soil hydrology on greenhouse-gas production and consumption will be important for the future management of these sites.

Soil moisture is a major factor governing the dynamics and direction of $\mathrm{CH}_{4}$ exchange between soils and the atmosphere as it limits diffusive transport of gases in the soil (Striegl, 1993) and due to the creation of aerobic and anaerobic habitats that select for methane-oxidizing bacteria (methanotrophs) and methane-producing archaea (methanogens), respectively (Le Mer and Roger, 2001; Segers, 1998). Other important environmental drivers of $\mathrm{CH}_{4}$ dynamics in soils include soil temperature (Curry, 2009) and groundwater level (Askaer et al., 2011). Furthermore, plant mediated $\mathrm{CH}_{4}$ emission through aerenchyma tissue can be important in wetlands (Askaer et al., 2011). Also, remnants in form of root exudates and litter also determine the amount and composition of the organic pool available for the anaerobic decomposers that deliver the precursor products (acetate, $\mathrm{H}_{2}$ and $\mathrm{CO}_{2}$ ) for the anaerobic methanogens (Bridgham et al., 2013). 
At atmospheric $\mathrm{CH}_{4}$ concentrations, as found in well-aerated soils, it is suggested that high-affinity, low-capacity methanotrophs primarily oxidize $\mathrm{CH}_{4}$ (Bengtson et al., 2009; Kolb, 2009) whereas at elevated $\mathrm{CH}_{4}$ concentrations, such as in wetland soils, low-affinity, high-capacity methanotrophs are predominantly active (Christiansen et al., 2015; Hanson and Hanson, 1996). Gulledge and Schimel (1998) showed that $\mathrm{CH}_{4}$ oxidation of atmospheric $\mathrm{CH}_{4}$ displayed similar parabolic relationships to soil moisture for taiga and tundra upland and wetland soils in Alaska, with maximum $\mathrm{CH}_{4}$ oxidation capacity at $20-40 \%$ of water-holding capacity (WHC). This could indicate that high-affinity methanotrophs were present in both upland and wetland soils. However, at elevated $\mathrm{CH}_{4}$ concentrations temperate hydromorphic soils have higher oxidation capacity than upland soils (Christiansen et al., 2012), indicating that the functioning and diversity of methanotrophic community in wetter soils are different than from those in upland soils (Bender and Conrad, 1995; Christiansen et al., 2015).

While wet soils can be methane sources due to active methanogenic communities, upland soils have also been shown to contain methanogens (Angel et al., 2012). These communities can be activated to produce $\mathrm{CH}_{4}$ under prolonged anaerobic conditions, but rates are markedly smaller than in continually-saturated soil (Christiansen et al., 2012). It has been shown that logging operations reduce $\mathrm{CH}_{4}$ oxidation and may even turn the soil in to a $\mathrm{CH}_{4}$ source due to compaction, which promotes water-logging and anaerobic conditions. This is associated with a decline in methaneoxidizing bacteria and occurrence of an active community of methane-producing microbes (methanogens) that may persist long after operations cease (Frey et al., 2011). Tree harvesting also reduces evapotranspiration, thus increasing the overall water content of the vadose zone and may raise water table in parts of the landscape. Thus, upland forest soils can shift from mitigating to contributing to rising atmospheric $\mathrm{CH}_{4}$ concentrations, dictated by the interactions between soil moisture dynamics and functional microbial groups of methanotrophs and methanogens. Currently, 
we lack basic knowledge of the soil moisture-microbe relationships for upland and wet soils, and so do not know if soil hydrological changes will lead to similar or differentiated responses of $\mathrm{CH}_{4}$ consumption and production rates in these contrasting environments.

To address this knowledge gap we hypothesize that potential rates of high- and low affinity $\mathrm{CH}_{4}$ oxidation and $\mathrm{CH}_{4}$ production is highest in wet forest soils due to a higher abundance of bacterial methanotrophs and archaeal methanogens. Accordingly, we hypothesize that wet forest soils will display net $\mathrm{CH}_{4}$ oxidation capacity over a wider range of soil moisture contents than upland forest soils. We sampled the organic soils across a natural hydrological gradient in upland (dry) and wet forest soils in a temperate rainforest on the Canadian Pacific coast. Soil samples from different depths $(0-10,10-25,25-35 \mathrm{~cm})$ were incubated at atmospheric $(\sim 2 \mathrm{ppm})$ and elevated $\mathrm{CH}_{4}$ concentrations $(\sim 10.000 \mathrm{ppm})$ and under anoxic conditions to obtain estimates of the potential rates of net $\mathrm{CH}_{4}$ oxidation and production. Abundances of bacterial methanotrophs and archaeal methanogens were subsequently quantified in the soil samples. Intact soil cores were similarly sampled from the same sites and subjected to a moisture manipulation experiment to study the moisture response of $\mathrm{CH}_{4}$ oxidation in the upland and wet forest soils.

\section{Materials and Methods}

\subsection{Site description}

The site was located close to the Beaver Lake, 20 km south-east of Port Hardy, Vancouver Island, Canada $\left(50^{\circ} 35^{\prime} 51.69^{\prime \prime} \mathrm{N}, 127^{\circ} 18^{\prime} 19.06^{\prime \prime} \mathrm{W}\right)$. Located in the very wet maritime Coastal Western Hemlock (CWHvm) biogeoclimatic zone of British Columbia (Meidinger and Pojar, 1991) the annual average temperature is $8^{\circ} \mathrm{C}$ and the area receives on average nearly $1900 \mathrm{~mm}$ of precipitation per year of which 3.4\% is as snow (The Weather Network, 2008). The elevation was 110-130 meters above sea level. 
Three typical forest types of the CWHvm zone included in the study were located along a topographic/soil moisture gradient with increasing wetness: Hemlock-Amabilis fir, Cedar-Hemlock and Shore pine bog representing a peatland forest. Elevation change from Hemlock-Amabilis to the Shore pine bog was 20 meters. The site has never been disturbed by modern logging activities and represents the primary forest type once predominant on the Canadian Pacific coast.

The Hemlock-Amabilis forest was dominated by western hemlock (Tsuga heterophylla (Raf.) Sarge.) with some amabilis fir (Abies amabilis), and an undergrowth dominated by blueberry (Vaccinum alaskaense). The Hemlock-Amabilis forest had naturally regenerated after windthrow 100 years previously and would be considered as an upland productive forest type (Banner et al., 2005). There are no indications at the site that the stand has not regenerated after windthrows or other natural disturbances. The Cedar-Hemlock forest was dominated by old-growth western red cedar (Thuja plicata Donn ex D. Don) with a dense undergrowth of salal (Gaultheria shallon Pursh) shrub. It has been suggested that Cedar-Hemlock forests are generally found on wetter sites than Hemlock-Amabilis forests (Sajedi et al., 2012), and at Beaver Lake the Cedar-Hemlock forest did occur in the transition zone between well-drained conditions and wet, saturated soils. The Shore pine bog forest was more open than the Hemlock-Amabilis and Cedar-Hemlock forests, and tree growth was stunted; thus it resembled the "bog woodland forest type" (Banner et al. 2005). The dominant tree species was shore pine (Pinus contorta var. contorta) and the open areas were covered with, grasses and Sphagnum and other mosses.

The mineral soils from a nearby Hemlock-Amabilis forest site had been previously characterized as Humo-Ferric Podzols (Blevins et al., 2006). However, the Beaver Lake site had organic soil horizons more than $40 \mathrm{~cm}$ deep, thus meeting the criterion for a deep Hemic Folisol (an upland organic soil; Soil Classification Working Group, 1998). In the Shore pine bog the soil consisted of peat. 
123 Soil carbon, nitrogen pools and $\mathrm{pH}$ values for the upland and wet forest soils were reported in

124 Christiansen et al. (2016). Mean organic soil carbon content $\left(\mathrm{kg} \mathrm{C} \mathrm{m}^{-2} \pm\right.$ standard deviation of the

125 mean) was $3.8 \pm 0.3$ and $4.1 \pm 0.4 \mathrm{~kg} \mathrm{C} \mathrm{m}^{-2}$ for the upland and wet forest soils, respectively. The

126 average total $\mathrm{N}$ pool $\left(\mathrm{kg} \mathrm{N} \mathrm{m}^{-2}\right)$ was $0.1 \pm 0.01$ and $0.2 \pm 0.03 \mathrm{~kg} \mathrm{~N} \mathrm{~m}^{-2}$ for the upland and wet forest

127 soils, respectively. Upland soils were more acidic ( $\mathrm{pH}: 3.6 \pm 0.2)$ than wet forest soils ( $\mathrm{pH}: 4.5 \pm 0.3$ ).

128

129

130

131

132

133

134

\subsection{Soil sampling for incubation experiments}

2.2.1 Potential net $\mathrm{CH}_{4}$ oxidation and production

In July 2012 intact soil samples in three depth classes $(0-10,10-25$ and 25-35 cm) were retrieved from three subplots in Hemlock-Amabilis, Cedar-Hemlock and Shore pine bog sites at Beaver Lake, respectively, (supplementary Fig. S1) corresponding to the location of in situ flux measurements of $\mathrm{CH}_{4}$ exchange (Christiansen et al., 2016). Subplots were distanced at least 50 meters apart to minimize risk of spatial autocorrelation. Sampling of soil samples were distributed randomly around the flux chambers in each subplot. In the upland soils a small pit $(10 \mathrm{x} 10 \mathrm{~cm})$ was excavated to $35 \mathrm{~cm}$ depth and from the wall an intact sample (on average $200 \mathrm{~cm}^{3}-100 \mathrm{~g}$ fresh weight) was retrieved by cutting loose the remaining three sides with a soil-knife. In the wet forest soils an intact sample (on average $75-100 \mathrm{~cm}^{3}-100 \mathrm{~g}$ fresh weight) was sampled in a similar manner and the volume was lower due to the wet state of the soil. The maximum sampling depth of $35 \mathrm{~cm}$ in all three forests was chosen due to a combination of impenetrable subsurface below this level due to buried logs in the upland soils of the Cedar-Hemlock and Hemlock-Amabilis and elevated groundwater table in the wet forest soils of the Shorepine Bog and Cedar-Hemlock.

A total of 67 samples were collected; 19, 27 and 21 from HA, Cedar-Hemlock and Shore pine bog plots, respectively (Table 1). Of the 67 samples, 28 were sampled in the upland soils at Beaver Lake (19 from Hemlock-Amabilis and 9 from Cedar-Hemlock), and the remaining 39 were sampled in 
the wet, hydromorphic soils (18 Cedar-Hemlock and 21 from Shore pine bog). Samples were transferred to ziplock bags and carefully placed in a cooler with ice so as not to cause degradation of the structure of the sample during transport. At arrival to the laboratory samples were transferred to a refrigator $\left(4^{\circ} \mathrm{C}\right)$ and stored in the state as when sampled until incubation. The samples were maintained in this state for two weeks (Cedar-Hemlock and Hemlock-amabilis) and 5 weeks (Shore pine bog) before the first high-affinity $\mathrm{CH}_{4}$ oxidation experiment began.

\subsubsection{Mesocosm study: Soil moisture response of net $\mathrm{CH}_{4}$ exchange}

For this experiment one intact soil core (volume of $785 \mathrm{~cm}^{3}$ ) from $0-10 \mathrm{~cm}$ were sampled within the chamber collar used for in situ measurements of $\mathrm{CH}_{4}$ exchange (Christiansen et al., 2016) in each of the subplots within the three forest types resulting in a total of 9 intact cores (Table 1). During this previous study no observable differences in vegetation abundance or species composition had occurred within the chamber perimeter during the study and no differences in soil moisture content within or outside the collar were detected. Together, this indicates that the intact soil cores used for the mesocosm study represented the conditions of the surrounding areas.

\section{[PLACEMENT of Table 1]}

\subsection{Potential net $\mathrm{CH}_{4}$ oxidation and production}

For determination of potential net $\mathrm{CH}_{4}$ oxidation, $40 \mathrm{~g}$ of fresh weight was subsampled and homogenized from each of the intact fresh samples. Each subsample of $40 \mathrm{~g}$ were incubated at field moisture in glass jars with a headspace volume of $446 \mathrm{~mL}$ under atmospheric $\mathrm{CH}_{4}$ concentration (Hemlock-amabilis: 2.3 ppm, Cedar-Hemlock: 1.7 ppm, Shore pine bog: $1.9 \mathrm{ppm}$ ) for 46 hours to target high-affinity methanotrophs (Christiansen et al., 2012). The initial ambient $\mathrm{CH}_{4}$ concentrations varied due to the different external air circulation in the building. The sample size of $40 \mathrm{~g}$ fresh weight sample were determined to obtain a headspace volume soil weight ratio of 1:10 
following the ratio used in earlier incubation studies (Bárcena et al., 2014; Christiansen et al., 2012). Samples were incubated for 46 hours; after 0, 3, 22, 27 and 46 hours gas samples ( $3 \mathrm{~mL})$ were extracted through a butyl rubber septum in the lid using a 5-mL syringe.

Following the incubation with initial atmospheric $\mathrm{CH}_{4}$ concentration (1.7 to $2.3 \mathrm{ppm}$ ), the jars were opened and flushed with atmospheric air to restore headspace conditions prior to the incubation and stored at $4^{\circ} \mathrm{C}$ with lids on loosely to facilitate oxygen exchange. Before the second incubation experiment that targeted low-affinity methanotrophs each jar+sample was weighed. Any weight loss was interpreted as evaporation and sufficient demineralized water was added to compensate for this loss. From September $17^{\text {th }}-28^{\text {th }}$ the soil samples from Hemlock-Amabilis and Cedar-Hemlock were incubated under elevated $\mathrm{CH}_{4}$ concentration (HA: 9529 ppm, $\mathrm{CH}$ : 9970 ppm) to target lowaffinity methanotrophs (Christiansen et al., 2012). Gas samples (3 mL) were extracted as above at 0, 46, 94, 190 and 262 hours after closure. Shore pine bog samples were incubated under elevated $\mathrm{CH}_{4}$ concentration (Shore pine bog: $10375 \mathrm{ppm}$ ) and samples were retrieved at 0, 23, 47 and 197 hours after closure. The elevated $\mathrm{CH}_{4}$ concentrations were achieved by injecting around $4.5 \mathrm{~mL}$ of $100 \%$ pure $\mathrm{CH}_{4}$ together with $35 \mathrm{~mL}$ of synthetic air. This also resulted in the jars being pressurized in order to compensate for loss from the sampling and to avoid negative pressure. Following the incubation, soil samples were dried to constant weight at $50^{\circ} \mathrm{C}$ for 48 hours to determine gravimetric water content.

For determination of potential net $\mathrm{CH}_{4}$ production $20 \mathrm{~g}$ were subsampled and homogenized from each of the fresh soil samples stored in the refrigator. The samples were placed in the glass jars with a headspace volume of $446 \mathrm{~mL}$. It was observed that adding a maximum of $14 \mathrm{~mL}$ of demineralized water to the upland soil samples (from Hemlock-Amabilis and Cedar-Hemlock) was adequate to fully saturate the soil sample in water and likely create anoxic conditions in the saturated soil; for the wet forest soils (from Cedar-Hemlock and Shore pine bog) which were already saturated, no 
additional water was added. The jars were closed and flushed with $\mathrm{N}_{2}$ continuously for 3 min at a flow rate of $3 \mathrm{~L} \mathrm{~min}^{-1}$ and subsequently evacuated for $3 \mathrm{~min}$ by inserting a running vacuum pump through the rubber septum in the lid. This sequence was repeated three times, so as to allow degassing of any dissolved gas in the demineralized water. The jars were pressurized by injecting $40 \mathrm{~mL}$ of pure $\mathrm{N}_{2}$ before incubation in order to compensate for the loss from the sampling and to avoid negative pressure. The gas samples $(3 \mathrm{~mL})$ were retrieved through a butyl rubber septum in the lid using a 5-mL syringe. The incubation lasted 184 days and samples were retrieved at day 0,3 , $8,16,29,52,77,108,128,168$ and 184 . Following the incubation soil samples were dried to constant weight at $50^{\circ} \mathrm{C}$ for 48 hours to determine gravimetric water content.

$\mathrm{CH}_{4}$ concentration in the gas samples for both $\mathrm{CH}_{4}$ consumption and production experiments were analyzed by manual injecting $2.5 \mathrm{~mL}$ of the sample immediately after sampling into a 5890 Series II gas chromatograph equipped with a flame ionization detector (FID). The carrier gas was He (flow rate of $35 \mathrm{ml} \mathrm{min}^{-1}$ ) and inlet and oven temperature was set to $70^{\circ} \mathrm{C}$. For $\mathrm{CH}_{4}$ measurements the GC was equipped with a Hayesep R packed column (Agilent Technlogies, Santa Clara, CA, USA). Synthetic air was used for $\mathrm{O}_{2}$ source and $\mathrm{H}_{2}$ as fuel for the FID.

[Moved from 2.4 Flux calculation] Initially, the rates $\left(\mathrm{ppm} \mathrm{h}^{-1}\right)$ were compared to the observed rates for three empty bottles. Any rates larger than the average rate of the empty bottles were assumed to be above the detection limit of the experimental setup. High-affinity and low-affinity net $\mathrm{CH}_{4}$ oxidation rates were calculated with linear regression using Microsoft Excel software (Microsoft, Seattle, WA, USA) (see supplementary Figure S2 and S3). For the Shore pine Bog only the first three data points were used in the calculation of the low affinity $\mathrm{CH}_{4}$ oxidation rate, representing a conservative estimate. The headspace of each incubation jar was determined after incubation experiments by weighing the jar without soil and weighing the jar completely filled with water. The weight difference of the water in grams was equivalent to the total headspace volume in $\mathrm{cm}^{3}$ as it 
217 was assumed that $1 \mathrm{~g} \mathrm{H}_{2} \mathrm{O}=1 \mathrm{~cm}^{3}$. $\mathrm{CH}_{4}$ concentrations in ppm were converted to mass (moles)

218 using the ideal gas law, the molar volume at room temperature $\left(22^{\circ} \mathrm{C}\right)$ and the jar volume. $\mathrm{Net}^{\mathrm{CH}_{4}}$

219 oxidation and production rates were expressed as $\mathrm{nmol} \mathrm{CH}_{4} \mathrm{~g} \mathrm{dw}^{-1} \mathrm{~d}^{-1}$ and given in positive

220 numbers to indicate the process rate and not the direction of net exchange.

221 During the net $\mathrm{CH}_{4}$ production experiment, development of $\mathrm{CH}_{4}$ concentrations resembled typical

222 logistic growth. Consequently, a logistic function was used to estimate theoretical $\mathrm{CH}_{4}$

223 concentrations (see supplementary material Fig. S4). The maximum $\mathrm{CH}_{4}$ production rate was

224 assumed to be equal to the maximum rate of concentration change at the theoretical time $\left(t_{\max }\right)$. In

225 cases where $t_{\max }$ occurred after termination of the experiments, the maximum $\mathrm{CH}_{4}$ production rate

226 was calculated on $\mathrm{t}=184$ days, corresponding to the end of the incubation.

227

228

229

230

231

232

\subsection{Response of net $\mathrm{CH}_{4}$ exchange to soil moisture change}

The response of net $\mathrm{CH}_{4}$ exchange to changing soil moisture status was assessed by a mesocosm study where the $\mathrm{CH}_{4}$ exchange between the headspace and soil core was measured for intact soil cores $(0-10 \mathrm{~cm}$ depth) as the cores dried from maximum water-holding capacity (WHC) to air dry state.

[Moved] To measure the net $\mathrm{CH}_{4}$ exchange rate, the intact soil cores were placed in a sealed $2 \mathrm{~L}$ incubation vessel filled with atmospheric air with a $\mathrm{CH}_{4}$ concentration of $2 \mathrm{ppm}$. The headspace of the incubation vessel was connected to a laser spectroscopy greenhouse gas analyser (Picarro G2508; Picarro Inc., Santa Clara, CA, USA). To estimate the net exchange the intact soil core was placed inside the headspace and the air was circulated (flow rate of $250 \mathrm{~mL} \mathrm{~min}^{-1}$ ) in a closed loop for 30 minutes with the $\mathrm{CH}_{4}$ concentration was recorded every 2 seconds. The internal physical volume of the Picarro G2508 and tubing was $500 \mathrm{~mL}$ at $1 \mathrm{~atm}$, but due to the low operating pressure (140 Torr) of the measurement cell the effective volume was estimated to be $100 \mathrm{~mL}$, which was 
added to the volume of the incubation jar for flux calculations. The concentration change of $\mathrm{CH}_{4}$ in the headspace during the 30 minutes was used to calculate the net exchange of $\mathrm{CH}_{4}$. It was assumed that a decreasing headspace concentration indicated a net $\mathrm{CH}_{4}$ oxidation in the soil core. An enclosure time of 30 minutes was enough in most cases to detect a significant change in the concentration above the noise of the analyzer. This change was therefore attributed to processes in the soil impacting the headspace concentration. Dry mole fractions of $\mathrm{CH}_{4}$ were used for flux calculations to correct for water vapor dilution during the exchange measurement. If the change of $\mathrm{CH}_{4}$ concentration during the 30 minute enclosure was less than the precision of the instrument it was assumed that there was no detectable activity and this measurement was omitted from further analysis. Some cores did not show detectable activity for the entire range of drying from maximum WHC to air dry resulting in a total 81 out of 99 potential measurements of net $\mathrm{CH}_{4}$ oxidation. Out of these 81 measurements of net $\mathrm{CH}_{4}$ exchange 61 were detectable above the noise of the experimental setup.

Net $\mathrm{CH}_{4}$ exchange rates (nmol $\mathrm{CH}_{4} \mathrm{~g} \mathrm{dw}^{-1} \mathrm{~d}^{-1}$ ) were calculated with PROC NLIN using SAS software version 9.2 (SAS Institute Inc., Cary, NC, USA) as on most occasion the concentrations followed a non-linear (exponential) asymptotic development. Thus, the maximum flux was the slope of the regression curve at $\mathrm{t}=0$ (see supplementary material).

Maximum WHC was used as the maximum soil moisture content during the incubation experiment and was defined as the content of water in the core after free drainage ceased (Gulledge and Schimel, 1998). For the Shore pine bog and wet forest soils in Cedar-Hemlock the WHC was 100\% at sampling. To achieve $100 \%$ WHC for the cores from the upland soils in the Cedar-Hemlock and Hemlock-Amabilis forests the cores were saturated with demineralized water and left to drain freely until no more water could be observed flowing out from the core. At this point it was assumed that all nine cores were at $100 \% \mathrm{WHC}$ and the cores left for 24 hours under a lid to adjust to the new 
soil moisture level. The bottom of the core was covered with cotton gauze to keep the soil in place during the experiment, as the volume of the soil diminished due to water loss from evaporation. This volume change was measured by recording the height and diameter of the cores at each measurement and accounted for when converting $\mathrm{CH}_{4}$ concentrations in ppm to mass.

Between each measurement of the net $\mathrm{CH}_{4}$ exchange the cores were placed together in a plastic box. The box was partly covered with a lid which slowed down the drying. The cores were air-dried at room temperature. The incubation experiment lasted for 37 days and measurements of the $\mathrm{CH}_{4}$ exchange were performed at $0,2,7,9,14,20,23,27,30,34$ and 37 days potentially providing 11 different pairs of soil moisture and net $\mathrm{CH}_{4}$ exchange rates for each core. Before each measurement of net $\mathrm{CH}_{4}$ exchange the weight of the cores were recorded. After the last incubation cores were left to air dry to constant weight and this weight was used to express the rate on a dry-weight basis. The net $\mathrm{CH}_{4}$ exchange rates for each core were standardized to a percentage of the maximum net $\mathrm{CH}_{4}$ exchange rate observed for that particular core. In this way it was possible to use all flux measurements performed for upland and wet forest soils, respectively, to compute the optimal WHC for net $\mathrm{CH}_{4}$ exchange.

\subsection{Microbial analyses}

Following the incubation experiments for potential net $\mathrm{CH}_{4}$ oxidation and production, $0.25 \mathrm{~g}$ of soil was extracted from each sample for genomic DNA analysis. The PowerSoil DNA Isolation kit (MO BIO Laboratories Inc., CA, USA) was used to extract the DNA in the sample. DNA quantity (ng L'

${ }^{1}$ ) was determined using Quant-IT PicoGreen dsDNA Assay kit (LIFE Technologies, CA, USA) and DNA was checked on $1 \%$ agarose gel.

Quantitative PCR was used to determine the abundance of the functional genes involved in $\mathrm{CH}_{4}$ oxidation (particulate methane mono-oxygenase subunit A, pmoA) and production (methyl 
conenzyme $\mathrm{M}$ reductase, $m c r A$ ). The qPCR was performed in $20-\mu 1$ reactions with $\sim 5$-ng template DNA added to Power SYBR ${ }^{\circledR}$ Green PCR Master Mix (Life Technologies Corp., Carlsbad, U.S.A.), $0.5 \mu \mathrm{M}$ of each primer and $200 \mathrm{ng} \mu \mathrm{l}^{-1}$ bovine serum albumin (BSA) to increase PCR efficiency. Reactions were carried out with an Applied Biosystems ${ }^{\circledR}$ StepOnePlus ${ }^{\mathrm{TM}}$ real-time PCR system. Quantitative PCR of the $m c r A$ gene in methanogens used ML-F and ML-R primers (Luton et al., 2002), with initial denaturation step of $5 \mathrm{~min}$ at $95^{\circ} \mathrm{C}$ and 40 cycles of $95^{\circ} \mathrm{C}$ denaturation for $30 \mathrm{~s}$, $56^{\circ} \mathrm{C}$ annealing for $45 \mathrm{~s}$ and $68^{\circ} \mathrm{C}$ extension for $45 \mathrm{~s}$, followed by fluorescence quantification at the end of a $82^{\circ} \mathrm{C}$ step for $10 \mathrm{~s}$ (modified from Freitag et al., 2010). Standard curves for $m c r A$ qPCR were used triplicate 10 -fold dilutions from $10^{3}$ to $10^{8}$ copies of a 420-bp $\mathrm{mcr} A$ amplicon from Methanolinea mesophila that overlaps the ML-F and ML-R primer regions in the mcrA gene, using $m c r A-245-\mathrm{f}$ (AGATCTGGCTCGGCTCCTAC) and $m c r A-743-\mathrm{r}$ (TAGTTGGGTCCACGGAGTTC) primers. The development of the amplicon-based standard curve for mcrA quantification is described in Christiansen et al. (2016). Standard curves showed an amplification efficiency of $101.3 \%\left(\mathrm{R}^{2}=0.99\right)$. Quantitative PCR of $p m o A$ used primers A189F and Mb661r (Bourne et al., 2001). Conditions included an initial denaturation step of 5 min at $95^{\circ} \mathrm{C}$ and 40 cycles of $95^{\circ} \mathrm{C}$ denaturation for $30 \mathrm{~s}, 64^{\circ} \mathrm{C}$ annealing for $45 \mathrm{~s}, 68^{\circ} \mathrm{C}$ extension for $45 \mathrm{~s}$, followed by fluorescence quantification at the end of a $86.5^{\circ} \mathrm{C}$ step for $16 \mathrm{~s}$ (modified from Freitag et al. (2010)). Standard curves for $p m o A$ were created using triplicate 10 -fold dilutions from $10^{3}$ to $10^{8}$ copies of Methylococcus capsulatus genomic DNA. Standard curves showed an amplification efficiency of $78.8 \%\left(\mathrm{R}^{2}=0.97\right)$. The $m m o X$ gene from facultatively methanotrophic Beijerinckiaceae was not quantified in this work. No methanotrophic Beijerinckiaceae (e.g., Methylocella sp.) were identified in $16 \mathrm{~S}$ sequences in a nearby experimental site (data not shown). Nevertheless, by only quantifying $p m o A$ abundance this study focuses on methanotrophs that contain the particulate form of methane monooxygenase. 


\subsection{Statistics}

312 All statistical analyses used SAS software version 9.3 (SAS Institute Inc., Cary, NC, USA).

313 Significance was accepted at $\mathrm{p}<0.05$.

314

315

316

317

A Wilcoxon non-parametric analysis using the PROC NPAR1WAY was used to test for differences in potential net $\mathrm{CH}_{4}$ oxidation by high and low-affinity methanotrophs and potential $\mathrm{CH}_{4}$ production (section 2.3) and abundance of the pmoA and $m c r A$ genes (section 2.5), respectively, between soil types (wet and upland) as well as sampling depth.

All flux measurements performed for the upland and wet forest soils, respectively, in the soil moisture response experiment (section 2.4) were used to estimate the optimal \%WHC for net $\mathrm{CH}_{4}$ oxidation. The vertex of the parabola $(-\mathrm{b} / 2 \mathrm{a})$ derived from polynomial regression using Proc HPLNMOD between standardized $\mathrm{CH}_{4}$ oxidation rates and WHC was interpreted as the optimal \%WHC for net $\mathrm{CH}_{4}$ oxidation. The vertex was computed in Proc HPLNMOD using the estimate command that applies the Delta method, $95 \%$ confidence intervals of the vertex and standard error of the vertex. In case the $95 \%$ confidence intervals of the vertex (optimal \%WHC) for the upland and wet forest soil regressions did not overlap it was assumed that the optimal \% WHC for net $\mathrm{CH}_{4}$ oxidation differed between upland and wet forest soils at the Beaver Lake site.

\section{Results and Discussion}

\subsection{Potential $\mathrm{CH}_{4}$ oxidation and production}

\section{[PLACEMENT OF FIGURE 1]}

In all three types of incubation experiments there was a significant difference between upland and wet forest soils across all soil depths for potential net $\mathrm{CH}_{4}$ oxidation rates of high- and low-affinity methanotrophs as well as potential net $\mathrm{CH}_{4}$ production rates, respectively. At atmospheric 
concentrations (e.g. at an initial headspace concentration of $\sim 2 \mathrm{ppm}$ ), wet forest soils (median $=$ $0.054 \mathrm{nmol} \mathrm{CH}_{4} \mathrm{~g} \mathrm{dw}^{-1} \mathrm{~d}^{-1}$ ) oxidized more $\mathrm{CH}_{4}$ than upland soils (median $=0.036 \mathrm{nmol} \mathrm{CH}_{4} \mathrm{~g} \mathrm{dw}^{-1}$ $\left.\mathrm{d}^{-1}\right)$ (Fig. 1A), although the absolute difference was small and there was considerable variation in net $\mathrm{CH}_{4}$ oxidation rates among samples. Although, we did observe different initial $\mathrm{CH}_{4}$ headspace concentrations during incubation, we do not attribute these differences in initial conditions to the observed differences in high-affinity $\mathrm{CH}_{4}$ oxidation rates. It has been reported that headspace concentration need to be increased at least one-order of magnitude over our observed difference to impact oxidation rates (Bender and Conrad, 1995). The high-affinity net $\mathrm{CH}_{4}$ oxidation rates in both upland and wet forest soils were small compared to earlier incubation studies $\left(0.33-1.7 \mathrm{nmol} \mathrm{CH}_{4}\right.$ $\mathrm{g} \mathrm{dw}^{-1} \mathrm{~d}^{-1}$ (Christiansen et al., 2012); $0.24-4.8 \mathrm{nmol} \mathrm{CH}_{4} \mathrm{~g} \mathrm{dw}^{-1} \mathrm{~d}^{-1}$ (Reay et al., 2005)). There was no apparent relation between high-affinity net $\mathrm{CH}_{4}$ oxidation rates and sampling depth for either upland or wet forest soils (Table 2). However, in the upland soils the highest rates were in the middle depth $(10-25 \mathrm{~cm})$ and in the wet soils the high-affinity net $\mathrm{CH}_{4}$ oxidation rates declined with depth and were significantly different between the top $(0-10 \mathrm{~cm})$ and the bottom depths $(25-35 \mathrm{~cm})$ (Table 2). The increase of high-affinity net $\mathrm{CH}_{4}$ oxidation with depth has been documented for a wide range of upland soil types (Juncher Jørgensen et al., 2014; Koschorreck and Conrad, 1993) and the data from the upland soils at Beaver Lake indicate that similar regulation of the activity of high-affinity methanotrophs are at play.

[Placement of table 2]

At elevated headspace $\mathrm{CH}_{4}$ concentrations (around $10.000 \mathrm{ppm}$ ), median net $\mathrm{CH}_{4}$ oxidation rates in the upland and wet forest soils were 9.8 and $127 \mathrm{nmol} \mathrm{CH}_{4} \mathrm{~g} \mathrm{dw}^{-1} \mathrm{~d}^{-1}$, and thus oxidized $\mathrm{CH}_{4} 270$ and over 2000 times faster than when incubated at atmospheric $\mathrm{CH}_{4}$ concentrations, respectively (Fig. 1B). It is well known that $\mathrm{CH}_{4}$ oxidation rates increase with headspace $\mathrm{CH}_{4}$ concentrations (Bender and Conrad, 1995) and as such these results are consistent with the current understanding 
357 of $\mathrm{CH}_{4}$ oxidation under different $\mathrm{CH}_{4}$ concentrations. It is generally assumed that low-affinity

358 (Type I) methanotrophs, which are more abundant in wetland soils than in well-drained soils, are

359 active under elevated $\mathrm{CH}_{4}$ concentrations (Christiansen et al., 2015; Hanson and Hanson, 1996).

360 Thus, we should expect higher net $\mathrm{CH}_{4}$ oxidation in wet soils than in upland soils under elevated

$361 \mathrm{CH}_{4}$. This was also shown in upland and hydromorphic soils in a temperate Danish forest

362 (Christiansen et al., 2012); rates of low-affinity $\mathrm{CH}_{4}$ oxidation in upland $\left(6.3-8.3 \mathrm{nmol} \mathrm{CH}_{4} \mathrm{~g} \mathrm{dw}^{-1}\right.$

$\left.363 \mathrm{~d}^{-1}\right)$ and wet forest soils $\left(67-117 \mathrm{nmol} \mathrm{CH}_{4} \mathrm{~g} \mathrm{dw}^{-1} \mathrm{~d}^{-1}\right)$ are similar to the median values for upland

364 (9.8 nmol CH $\left.4 \mathrm{~g} \mathrm{dw}^{-1} \mathrm{~d}^{-1}\right)$ and wet soils (127 nmol CH $\left.4 \mathrm{~g} \mathrm{dw}^{-1} \mathrm{~d}^{-1}\right)$ at Beaver Lake (Fig. 1B). In the

365 upland soils, low-affinity net $\mathrm{CH}_{4}$ oxidation rates displayed the same pattern as observed for high-

366 affinity net $\mathrm{CH}_{4}$ oxidation, and rates were significantly higher in the $10-25 \mathrm{~cm}$ layer. In the wet

367 forest soils, low-affinity net $\mathrm{CH}_{4}$ oxidation rates declined with depth, but due to substantial

368 variability there were no significant differences among depths (Table 2). However, the low-affinity

369 net $\mathrm{CH}_{4}$ oxidation rates in the wet soils (in Shore pine bog (peat) and Cedar-Hemlock) showed

370 different patterns with depth - in Shore pine bog (peat) soils net $\mathrm{CH}_{4}$ oxidation rates declined

371 significantly $(\mathrm{p}=0.0004)$ with depth, whereas net $\mathrm{CH}_{4}$ oxidation rates were constant with sampling

372 depth in Cedar-Hemlock. It was shown that methanotrophic communities and their potential

373 oxidation of $\mathrm{CH}_{4}$ were different and higher, respectively, in soils under vascular plants that

374 transport oxygen in to the root zone compared to other types of vegetation that did not have this

375 ability (Chen et al., 2008). In line with this, the significant variation of the low-affinity net $\mathrm{CH}_{4}$

376 oxidation in the Shore pine bog (peat) and not in the Cedar-Hemlock could be due to localized

377 adaptation of the methanotrophs community to specific soil types under the different plant

378 community structure that was observed in the field in these two forest types.

379 According to expectations, wet forest soils produced $\mathrm{CH}_{4}$ under anoxic conditions (median $=497$

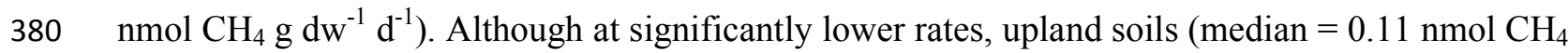


$381 \mathrm{~g} \mathrm{dw}^{-1} \mathrm{~d}^{-1}$ ) were also capable of methanogenesis, indicating that methane-producing organisms (e.g. 382 methanogens) are present in the upland soils (Fig. 1C). It has been argued that methanogens can be 383 reactivated from a dormant stage in well-drained soils if anoxic conditions are created (Angel et al., 2012). There was high variability of net $\mathrm{CH}_{4}$-production rates in wet forest soils (Fig. 1C), but the range of net $\mathrm{CH}_{4}$ production rates was similar in Shore pine bog (peat) $\left(0.4-6877 \mathrm{nmol} \mathrm{CH}_{4} \mathrm{~g} \mathrm{dw}^{-1}\right.$ $\left.\mathrm{d}^{-1}\right)$ and wet soils from the Cedar-Hemlock forest $\left(0.14-4972 \mathrm{nmol} \mathrm{CH}_{4} \mathrm{~g} \mathrm{dw}^{-1} \mathrm{~d}^{-1}\right)$, exemplifying the spatial heterogeneity of $\mathrm{CH}_{4}$ formation in soils. However, net $\mathrm{CH}_{4}$ production rates in the

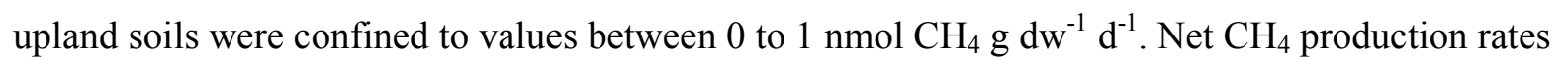
significantly decreased with sampling depth in both upland and wet forest soils.

\subsection{Methanotroph and methanogen abundance}

No effect of sampling depth on abundance of methanotrophs or methanogens was detected in either

392 forest type. However, abundances of both groups were significantly greater in wetland soils for the

393 entire sampling depth (Table 3). This is in line with the observations of significantly higher rates of 394 high- and low-affinity net $\mathrm{CH}_{4}$ oxidation and net $\mathrm{CH}_{4}$ production in the wet forest soils (Fig. 1).

395 However, there was no relationship between depth-specific net $\mathrm{CH}_{4}$ consumption or production 396 rates and gene abundances of $p m o A$ or $m c r A$, respectively (not shown).

The data on potential net $\mathrm{CH}_{4}$ oxidation and production rates and gene abundance offer insight in to how functional microbial groups differ between wet and upland forest soil and may aid in explaining spatial patterns of important biogeochemical fluxes. Given that the seasonal variability

401 in soil hydrological conditions in the wet soils are more pronounced than in the upland soils, due to

402 fluctuations in the water table, the methanotrophic community in the wet soils may be able to

403 oxidize $\mathrm{CH}_{4}$ under more variable hydrologic conditions than are the communities in the upland 
soils. This could explain the higher potential rates of net $\mathrm{CH}_{4}$ oxidation under contrasting conditions in the high- and low-affinity incubation experiments (Fig. 1A, B).

\subsection{Response of net $\mathrm{CH}_{4}$ exchange to soil moisture change}

\section{[PLACEMENT OF FIGURE 2]}

The response of net $\mathrm{CH}_{4}$ exchange to manipulated soil moisture (section 2.4) (Fig. 2A-B) showed that net $\mathrm{CH}_{4}$ oxidation was present in 60 out of 61 detected fluxes. This finding confirmed the postulation that the methanotrophic community in the wet forest soils was able to oxidize $\mathrm{CH}_{4}$ over a larger range of soil hydrological conditions than the upland soils. There was an increase of net $\mathrm{CH}_{4}$ oxidation with decreasing manipulated soil moisture content for both upland and wet forest soils (Fig. 2A), which concurs with previous laboratory and field studies (e.g. Christiansen et al., 2012; Gulledge and Schimel, 1998). $\mathrm{Net}_{\mathrm{CH}_{4}}$ oxidation rates were similar for upland and wet forest soils at $100 \%$ WHC, but as the manipulated soil moisture decreased, maximum net $\mathrm{CH}_{4}$ oxidation rates in the upland soils occurred at a higher WHC than in the wet forest soils (Fig. 2A). Two upland soil cores in the Cedar-Hemlock and Hemlock-Amabilis showed small rates of net $\mathrm{CH}_{4}$ production at $100 \%$ WHC (Fig. 2A) which was ascribed to erroneous flux calculation due to a large noise-to-signal ratio which resulted in over-fitting of the exponential regression model and these samples were not considered for further analyses.

To further explore the soil moisture dependency, the relative net $\mathrm{CH}_{4}$ oxidation rates (to the maximum rates for each core) for each observation in wet and upland soils were plotted against WHC (Fig. 2B), as per the approach of Gulledge and Schimel (1998). This allowed for direct comparison among cores, and reveals a distinctive pattern of net $\mathrm{CH}_{4}$ oxidation response to manipulated soil moisture (Fig. 2B). Net $\mathrm{CH}_{4}$ oxidation in both upland and wet forest soils followed a polynomial trend as documented by Gulledge and Schimel (1998). Whereas they concluded that diverse Alaskan soils showed the same response to WHC (Gulledge and Schimel, 1998) the data 
428 from Beaver Lake indicate a soil-type-specific response of net $\mathrm{CH}_{4}$ oxidation to soil drying. The

429 maximum relative rate of wet soils coincided with the minimum of upland soils at Beaver Lake

430 (Fig. 2A, B). The optimal WHC for net $\mathrm{CH}_{4}$ oxidation thus differed significantly between upland

431 (WHC: $77 \pm 1.0 \%$ corresponding to $31.7 \%$ volumetric water content) and wet (WHC: $50 \pm 4 \%$,

432 corresponding to $18.7 \%$ volumetric water content) forest soils, respectively.

433 4. Conclusion

434 This study demonstrated that soil moisture status of the soil controls the magnitude of potential net

$435 \mathrm{CH}_{4}$ oxidation and production in the Pacific temperate rainforest of Canada. Thus, there were

436 significantly higher potential rates of net $\mathrm{CH}_{4}$ oxidation and production in permanently wet forest

437 soils compared to well-drained upland forest soils.

438

439

440

441 442 archaea in these soils.

443

444

445

446

447

448 forest soils.

As expected, the wet forest soils produced $\mathrm{CH}_{4}$ in significantly higher amounts than upland forest soils and the abundance of methane producing archaea was many-fold larger in wet forest soils.

This study also contributes to the growing evidence that $\mathrm{CH}_{4}$ production can be induced in otherwise well-drained soils; this may be related to activation and growth of methane-producing

Under our specific experimental conditions which were targeted to create optimal conditions for both oxidation and production, respectively, wet forest soils oxidized significantly more $\mathrm{CH}_{4}$ at atmospheric ( $\sim 2 \mathrm{ppm})$ and elevated $(10.000 \mathrm{ppm}) \mathrm{CH}_{4}$ concentrations, indicating that the methanotrophic community was more active in the wet forest soils. This is supported by the significantly greater abundance of methanotrophs in the wet forest soils, compared to the upland 
449 A moisture manipulation experiment using mesocosms confirmed that the wet forest soils sustained 450 higher rates of net $\mathrm{CH}_{4}$ oxidation across a larger range of soil moisture conditions compared to 451 upland forest soils.

452 These findings suggest that upland and wet forest soils may displace differential response of net $453 \mathrm{CH}_{4}$ oxidation and production following changes in soil moisture which are important to consider in 454 future management and prediction of the $\mathrm{CH}_{4}$ dynamics in these soil types. Although our 455 measurements cannot be scaled to in situ conditions they do provide an empirical and quantitative 456 basis on which it can be hypothesized that 1) desiccation of upland forest soils in the Pacific 457 temperate rainforest due to drought may reduce the size of the $\mathrm{CH}_{4}$ sink, but is not likely to affect $458 \mathrm{CH}_{4}$ oxidation in the wet forest soils and 2) forest harvesting practices that lead to water logging in 459 upland soils could result in these areas becoming net sources of $\mathrm{CH}_{4}$. Further field studies are 460 needed to test these hypotheses.

\section{Acknowledgements}

462 The authors would like to thank the Carlsberg Foundation for funding the travel grant (no.

463 2011_01_0076) to JRC and Western Forest Products Inc. for lodging and access to the Beaver Lake 464 site. The work was also funded by a NSERC Discovery Grant to SJG. We thank Dr. Sean Smukler, 465 at Faculty of Land and Food Systems, University of British Columbia for letting us use his cavity 466 ring-down spectrometer to measure $\mathrm{CH}_{4}$ concentrations in the moisture manipulation experiment.

467 Lastly, we extend our gratitude to the two anonymous reviewers whose thorough and thoughtful 468 comments have greatly improved the paper.

\section{References}

469 Angel, R., Claus, P., Conrad, R., 2012. Methanogenic archaea are globally ubiquitous in aerated 
soils and become active under wet anoxic conditions. The ISME Journal 6, 847-862. doi:10.1038/ismej.2011.141

Askaer, L., Elberling, B., Friborg, T., Jørgensen, C.J., Hansen, B.U., 2011. Plant-mediated $\mathrm{CH}_{4}$ transport and $\mathrm{C}$ gas dynamics quantified in-situ in a Phalaris arundinacea-dominant wetland. Plant and Soil 343, 287-301. doi:10.1007/s11104-011-0718-x

Banner, A., LePage, P., Moran, J., de Groot, A., 2005. The HyP3 Project: Pattern, process and productivity in hypermaritime Forests of coastal British Columbia, Report 10. ed. B.C. Ministry of Forests, British Columbia, Canada, Victoria.

Bárcena, T.G., D’Imperio, L., Gundersen, P., Vesterdal, L., Priemé, A., Christiansen, J.R., 2014. Conversion of cropland to forest increases soil $\mathrm{CH}_{4}$ oxidation and abundance of $\mathrm{CH}_{4}$ oxidizing bacteria with stand age. Applied Soil Ecology 79, 49-58. doi:10.1016/j.apsoil.2014.03.004

Basiliko, N., Khan, A., Prescott, C.E., Roy, R., Grayston, S.J., 2009. Soil greenhouse gas and nutrient dynamics in fertilized western Canadian plantation forests. Canadian Journal of Forest Research 39, 1220-1235. doi:10.1139/X09-043

Bender, M., Conrad, R., 1995. Effect of $\mathrm{CH}_{4}$ concentrations and soil conditions on the induction of CH4 oxidation activity. Soil Biology and Biochemistry 27, 1517-1527. doi:10.1016/00380717(95)00104-M

Bengtson, P., Basiliko, N., Dumont, M.G., Hills, M., Murrell, J.C., Roy, R., Grayston, S.J., 2009. Links between methanotroph community composition and $\mathrm{CH}_{4}$ oxidation in a pine forest soil. FEMS MICROBIOLOGY ECOLOGY 70, 356-366. doi:10.1111/j.1574-6941.2009.00751.x

Blevins, L.L., Prescott, C.E., Van Niejenhuis, A., 2006. The roles of nitrogen and phosphorus in increasing productivity of western hemlock and western redcedar plantations on northern 
492

493

494

495

496

497

498

499

500

501

502

503

504

505

506

507

508

509

510

511

512

513

Vancouver Island. Forest Ecology and Management 234, 116-122.

doi:10.1016/j.foreco.2006.06.029

Bourne, D.G., McDonald, I.R., Murrell, J.C., 2001. Comparison of pmoA PCR Primer Sets as Tools for Investigating Methanotroph Diversity in Three Danish Soils. Applied and Environmental Microbiology 67, 3802-3809. doi:10.1128/AEM.67.9.3802-3809.2001

Bridgham, S.D., Cadillo-Quiroz, H., Keller, J.K., Zhuang, Q., 2013. Methane emissions from wetlands: biogeochemical, microbial, and modeling perspectives from local to global scales. Global Change Biology 19, 1325-1346. doi:10.1111/gcb.12131

Chen, Y., Dumont, M.G., McNamara, N.P., Chamberlain, P.M., Bodrossy, L., Stralis-Pavese, N., Murrell, J.C., 2008. Diversity of the active methanotrophic community in acidic peatlands as assessed by mRNA and SIP-PLFA analyses. Environmental Microbiology 10, 446-459. doi:10.1111/j.1462-2920.2007.01466.x

Christiansen, J.R., Gundersen, P., Frederiksen, P., Vesterdal, L., 2012. Influence of hydromorphic soil conditions on greenhouse gas emissions and soil carbon stocks in a Danish temperate forest. Forest Ecology and Management 284, 185-195. doi:10.1016/j.foreco.2012.07.048

Christiansen, J.R., Levy-Booth, D., Prescott, C.E., Grayston, S.J., 2016. Microbial and Environmental Controls of Methane Fluxes Along a Soil Moisture Gradient in a Pacific Coastal Temperate Rainforest. Ecosystems. doi:10.1007/s10021-016-0003-1

Christiansen, J.R., Romero, A.J.B., Jørgensen, N.O.G., Glaring, M.A., Jørgensen, C.J., Berg, L.K., Elberling, B., 2015. Methane fluxes and the functional groups of methanotrophs and methanogens in a young Arctic landscape on Disko Island, West Greenland. Biogeochemistry 122, 15-33. doi:10.1007/s 10533-014-0026-7 
514 Curry, C.L., 2009. The consumption of atmospheric methane by soil in a simulated future climate.

515 Biogeosciences Discussions 6, 6077-6110. doi:10.5194/bgd-6-6077-2009

516 Freitag, T.E., Toet, S., Ineson, P., Prosser, J.I., 2010. Links between methane flux and

517 transcriptional activities of methanogens and methane oxidizers in a blanket peat bog. FEMS

$518 \quad$ Microbiology Ecology 73, 157-165. doi:10.1111/j.1574-6941.2010.00871.x

519 Frey, B., Niklaus, P.A., Kremer, J., Lüscher, P., Zimmermann, S., 2011. Heavy-machinery traffic

520 impacts methane emissions as well as methanogen abundance and community structure in oxic

521 forest soils. Applied and Environmental Microbiology 77, 6060-6068.

522 doi:10.1128/AEM.05206-11

523 Gulledge, J., Schimel, J.P., 1998. Moisture control over atmospheric $\mathrm{CH}_{4}$ consumption and $\mathrm{CO}_{2}$

524 production in diverse Alaskan soils. Soil Biology and Biochemistry 30, 1127-1132.

525 doi:10.1016/S0038-0717(97)00209-5

526 Hanson, R.S., Hanson, T.E., 1996. Methanotrophic bacteria. Microbiological Reviews 60, 439-71.

527 Jassal, R., Black, A., Novak, M., Morgenstern, K., Nesic, Z., Gaumont-Guay, D., 2005.

528 Relationship between soil $\mathrm{CO} 2$ concentrations and forest-floor $\mathrm{CO}_{2}$ effluxes. Agricultural and

$529 \quad$ Forest Meteorology 130, 176-192. doi:10.1016/j.agrformet.2005.03.005

530 Juncher Jørgensen, C., Lund Johansen, K.M., Westergaard-Nielsen, A., Elberling, B., 2014. Net

531 regional methane sink in High Arctic soils of northeast Greenland. Nature Geoscience 8, 20-

532 23. doi:10.1038/ngeo2305

533 Kolb, S., 2009. The quest for atmospheric methane oxidizers in forest soils. Environmental

534 Microbiology Reports 1, 336-46. doi:10.1111/j.1758-2229.2009.00047.x 
535 Koschorreck, M., Conrad, R., 1993. Oxidation of atmospheric methane in soil: Measurements in the 536 field, in soil cores and in soil samples. Global Biogeochemical Cycles 7, 109-121. doi:10.1029/92GB02814

Le Mer, J., Roger, P., 2001. Production, oxidation, emission and consumption of methane by soils: A review. European Journal of Soil Biology 37, 25-50. doi:10.1016/S1164-5563(01)01067-6

Luton, P.E., Wayne, J.M., Sharp, R.J., Riley, P.W., 2002. The mcrA gene as an alternative to $16 \mathrm{~S}$ rRNA in the phylogenetic analysis of methanogen populations in landfill. Microbiology 148, 3521-3530. doi:10.1099/00221287-148-11-3521

Meidinger, D. V, Pojar, J., 1991. Ecosystems of British Columbia, Special Report Series. B.C. Ministry of Forests, British Columbia, Canada, Victoria.

Reay, D., Nedwell, D., Mcnamara, N., Ineson, P., 2005. Effect of tree species on methane and ammonium oxidation capacity in forest soils. Soil Biology and Biochemistry 37, 719-730. doi:10.1016/j.soilbio.2004.10.004

Sajedi, T., Prescott, C.E., Seely, B., Lavkulich, L.M., 2012. Relationships among soil moisture, aeration and plant communities in natural and harvested coniferous forests in coastal British Columbia, Canada. Journal of Ecology 100, 605-618. doi:10.1111/j.1365-2745.2011.01942.x

Segers, R., 1998. Methane production and methane consumption: a review of processes underlying wetland methane fluxes. Biogeochemistry 41, 23-51. doi:10.1023/A:1005929032764

Soil Classification Working Group, 1998. The Canadian System of Soil Classification, Third edition. Ottawa.

Striegl, R.G., 1993. Diffusional limits to the consumption of atmospheric methane by soils. 
557

\section{8}

559

560

561

562

563

Tables

Table 1 Description of soil sampling for incubation studies at the three forest types (Hemlock-

Amabilis, Cedar-Hemlock and Shore pine bog) at the Beaver Lake site.

\begin{tabular}{lllcc}
\hline Experiment & Forest type & $\begin{array}{l}\text { Soil hydrology } \\
\text { classification }\end{array}$ & Depth [cm] & $\begin{array}{c}\text { Number } \\
\text { samples }\end{array}$ \\
\hline $\begin{array}{llll}\text { Potential net } \\
\text { CH } H_{4}\end{array}$ & Hemlock- & Upland & $0-10$ & 9 \\
axidation & & Upland & $10-25$ & 9 \\
and & Cedar- & Upland & $25-35$ & 1 \\
production & Hemlock & Upland & $0-10$ & 3 \\
& & Upland & $10-25$ & 3 \\
& & Wet forest soil & $0-10$ & 3 \\
& & Wet forest soil & $10-25$ & 6 \\
& Shore pine & Wet forest soil & $25-35$ & 6 \\
& bog forest soil & $0-10$ & 9 \\
& & Wet forest soil & $10-25$ & 7 \\
Soil & Hemlock- & Wet forest soil & $25-35$ & 5 \\
moisture & amabilis & Upland & $0-10$ & 3 \\
response & Cedar- & Upland & & \\
& Hemlock & Wet forest soil & $0-10$ & 2 \\
& Shore pine & Wet forest soil & $0-10$ & 3 \\
& bog & & \\
\hline
\end{tabular}

The Weather Network, 2008. The Weather Network—statistics-Port Hardy, British Columbia, Canada (1961-1990) [WWW Document]. URL http://www.theweathernetwork.com/ca/forecasts/statistics/british-columbia/port-hardy (accessed 2.10.16).

Waring, R.H., Franklin, J.F., 1979. Evergreen Coniferous Forests of the Pacific Northwest. Science 204, 1380-1386. doi:10.1126/science.204.4400.1380 
565 Table 2 Average ( \pm S.E.) depth-specific potential net $\mathrm{CH}_{4}$ oxidation by high- and low-affinity 566 methanotrophs and potential net $\mathrm{CH}_{4}$ production

\begin{tabular}{|c|c|c|c|c|c|c|}
\hline \multirow[b]{2}{*}{ Depth $(\mathrm{cm})$} & \multicolumn{2}{|c|}{$\begin{array}{l}\text { High-affinity } \mathrm{CH}_{4} \text { oxi. } \\
\left(\mathrm{nmol} \mathrm{CH}_{4} \mathrm{~g} \mathrm{dw}^{-1} \mathrm{~d}^{-1}\right)\end{array}$} & \multicolumn{2}{|c|}{$\begin{array}{l}\text { Low-affinity } \mathrm{CH}_{4} \text { oxi. } \\
\left(\mathrm{nmol} \mathrm{CH}_{4} \mathrm{~g} \mathrm{dw}^{-1} \mathrm{~d}^{-1} \text { ) }\right.\end{array}$} & \multicolumn{2}{|c|}{$\begin{array}{l}\mathrm{CH}_{4} \text { production } \\
\left(\mathrm{nmol} \mathrm{CH}_{4} \mathrm{~g} \mathrm{dw}^{-1} \mathrm{~d}^{-1}\right)\end{array}$} \\
\hline & Upland & $\begin{array}{l}\text { Wet forest } \\
\text { soil }\end{array}$ & Upland & $\begin{array}{l}\text { Wet forest } \\
\text { soil }\end{array}$ & Upland & $\begin{array}{l}\text { Wet forest } \\
\text { soil }\end{array}$ \\
\hline $0-10$ & $0.032 \pm 0.006 \mathrm{a}$ & $0.077 \pm 0.012$ & $9.5 \pm 3$ & $460 \pm 123$ & $0.25 \pm 0.09$ & $2510 \pm 612$ \\
\hline $10-25$ & $0.050 \pm 0.008 b$ & $0.044 \pm 0.006$ & $18.5 \pm 3$ & $264 \pm 62$ & $0.11 \pm 0.03$ & $932 \pm 422$ \\
\hline $25-35$ & $0.013 \pm 0.001 \mathrm{a}$ & $0.043 \pm 0.008$ & $2.0 \pm 0.4$ & $78 \pm 31$ & - & $338 \pm 156$ \\
\hline
\end{tabular}

Table 3 Average ( \pm S.E.) log gene abundance of the functional genes $p m o A$ and $m c r A$ (per gram dry weight) that code for the enzymatic processes of methanotrophy $\left(\mathrm{CH}_{4}\right.$ production) and methanogenesis $\left(\mathrm{CH}_{4}\right.$ production) in upland and wet forest soils from three sampling depths $(0-10$, $10-25$ and $25-35 \mathrm{~cm})$.

\begin{tabular}{lllll}
\hline & \multicolumn{2}{l}{ Methanotrophs } & \multicolumn{2}{l}{ Methanogens } \\
& $\left(\log \# p m o A \mathrm{~g} \mathrm{dw}^{-1}\right)$ & $\left(\log \# m c r A \mathrm{~g} \mathrm{dw}^{-1}\right)$ \\
\hline Depth (cm) & Upland & Wet forest & Upland & Wet forest \\
& & soil & & soil \\
& & & & \\
\hline $0-10$ & $4.3 \pm 0.08$ & $5.7 \pm 0.34$ & $4.0 \pm 0.17$ & $6.6 \pm 0.29$ \\
$10-25$ & $4.2 \pm 0.12$ & $5.3 \pm 0.51$ & $4.1 \pm 0.18$ & $6.8 \pm 0.27$ \\
$25-35$ & $4.4 \pm 0.20$ & $5.4 \pm 0.21$ & $4.6 \pm 0.23$ & $6.1 \pm 0.36$ \\
Average & $4.3 \pm 0.08$ & $5.4 \pm 0.22^{* * *}$ & $4.3 \pm 0.13$ & $6.5 \pm 0.18^{* * *}$ \\
\hline
\end{tabular}


Figure captions
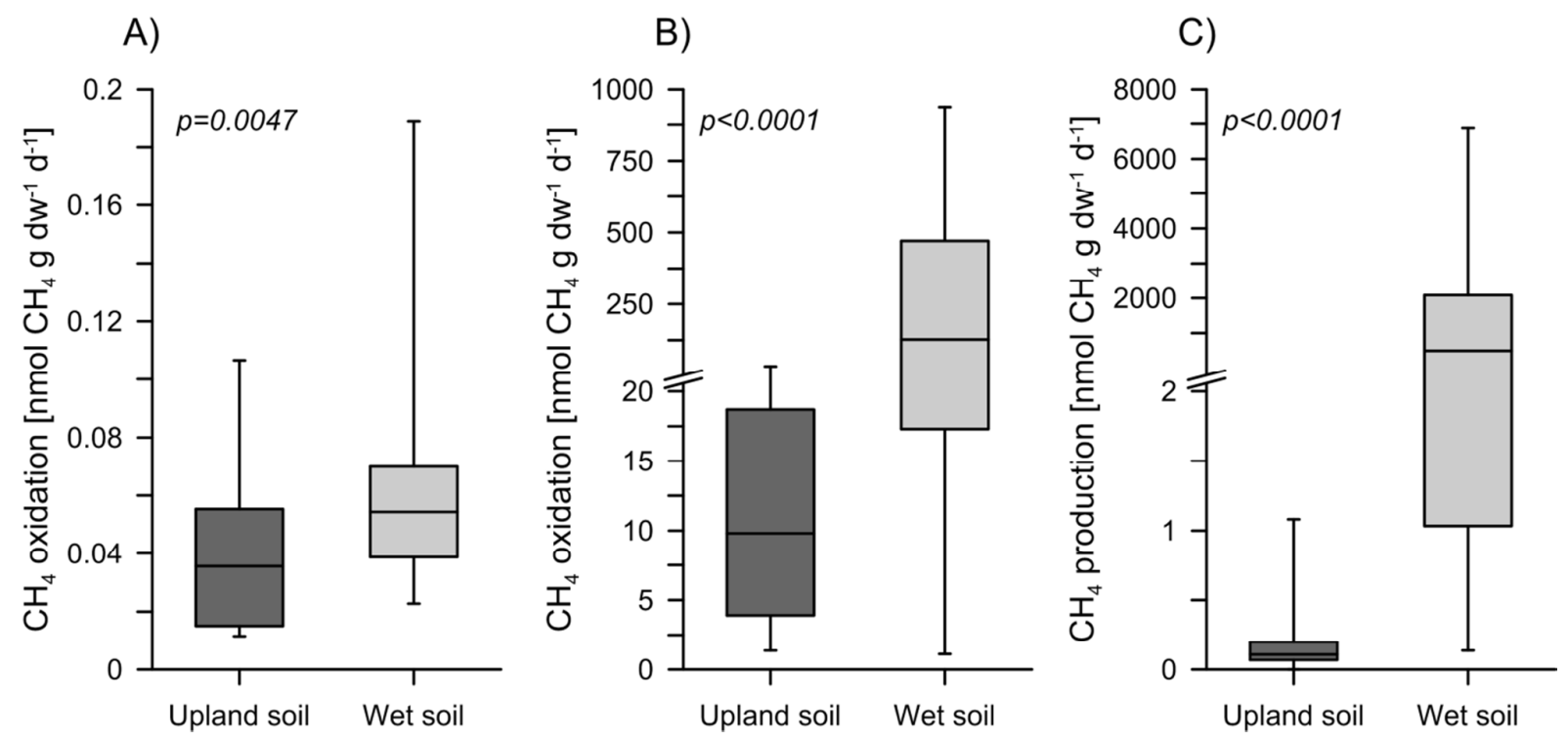

Figure 1 Box plots of A) high-affinity $\mathrm{CH}_{4}$ oxidation rates, B) low-affinity $\mathrm{CH}_{4}$ oxidation rates and C) $\mathrm{CH}_{4}$ production rates (nmol $\left.\mathrm{CH}_{4} \mathrm{~g} \mathrm{dw}^{-1} \mathrm{~d}^{-1}\right)$ in upland and wet forest soils across all depths $(0$ 10, $10-25$ and $25-35 \mathrm{~cm}$ ). Lines within boxes are the median, lower and upper edges of boxes represent the first and third quartiles, respectively, and bars indicate minimum and maximum values. 

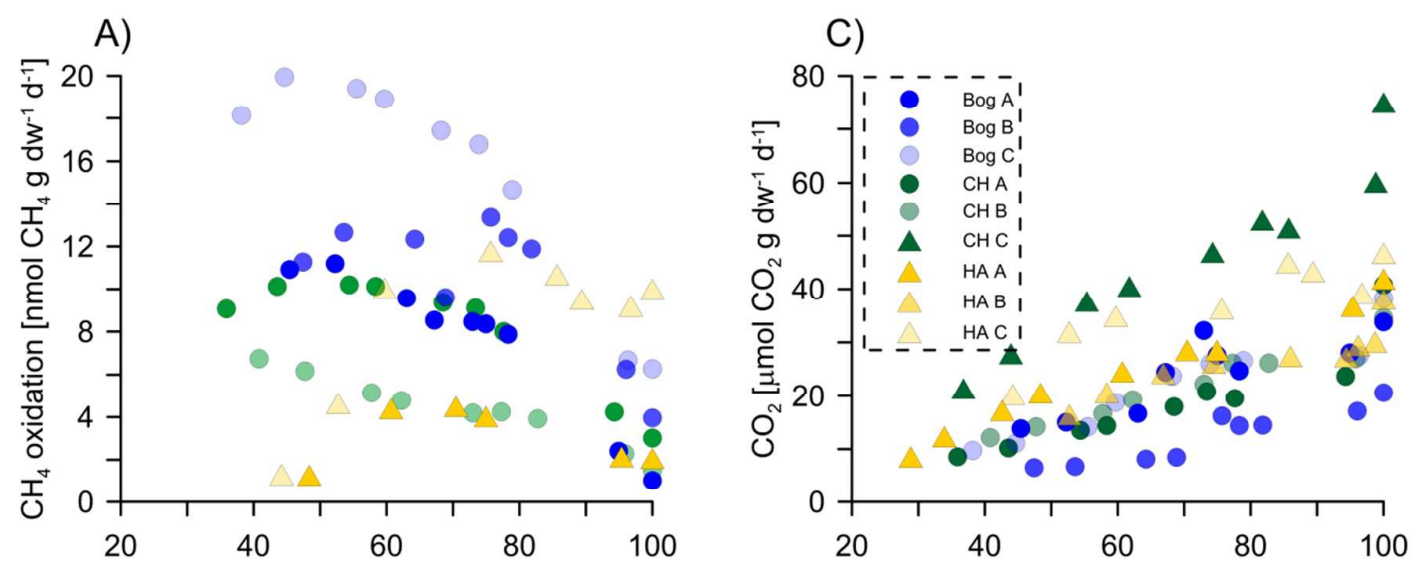

B)

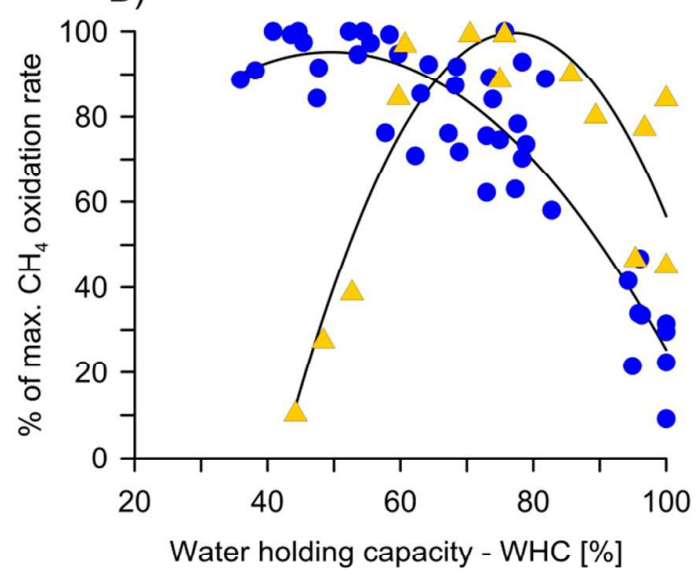

D)

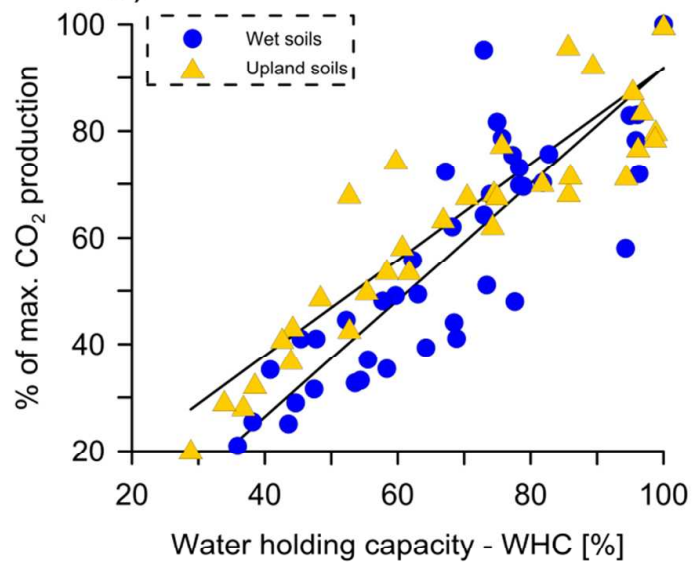

Wet: $\% \max \mathrm{CH}_{4}$ ox. $=27.7+2.7^{*} \mathrm{WHC}-0.027^{*} \mathrm{WHC}^{2}\left(R^{2}=0.78\right)$ Upland: \% max $\mathrm{CH}_{4}$ ox. $=-383+12.5^{\star} \mathrm{WHC}-0.081 \mathrm{WHC}^{2}\left(R^{2}=0.78\right)$

Wet: $\% \max \mathrm{CH}_{4}$ ox. $=1.09^{*} \mathrm{WHC}-17.3\left(R^{2}=0.79\right)$
Upland: $\% \max \mathrm{CH}_{4}$ ox. $=0.90^{*} \mathrm{WHC}+1.83\left(R^{2}=0.85\right)$

Figure 2 Relationships between soil water-holding capacity (\%) and net $\mathrm{CH}_{4}$ oxidation for upland and wet forest soils in the Shore pine bog (Bog), Cedar-Hemlock (CH) and Hemlock-amabilis (HA) forests at Beaver Lake. A) rates of net $\mathrm{CH}_{4}$ oxidation $\left(\mathrm{nmol} \mathrm{CH} \mathrm{g} \mathrm{dw}^{-1} \mathrm{~d}^{-1}\right)$. The letters $(\mathrm{A}, \mathrm{B}$ and C) following Bog, $\mathrm{CH}$ and $\mathrm{HA}$ define the subplots within each forest type, respectively. B) relative $\mathrm{CH}_{4}$ oxidation rate to maximum $\mathrm{CH}_{4}$ oxidation rates (\% of $\max \mathrm{CH}_{4}$ oxidation rate). The \% of max $\mathrm{CH}_{4}$ oxidation rate were expressed in $\%$ and calculated by normalizing the absolute $\mathrm{CH} 4$ oxidation rate to the maximum absolute $\mathrm{CH}_{4}$ oxidation rate for the specific core. Regression equations for $\%$ of $\max \mathrm{CH}_{4}$ oxidation rate and water-holding capacity for wet and upland soils, respectively, are presented in a box below B). 


\section{Electronic Supplementary Material}

for Christiansen et al. Soil moisture controls of methane and carbon dioxide exchange and microbial abundance in organic soils of the Pacific coastal rainforest in Canada

Soil sampling layout

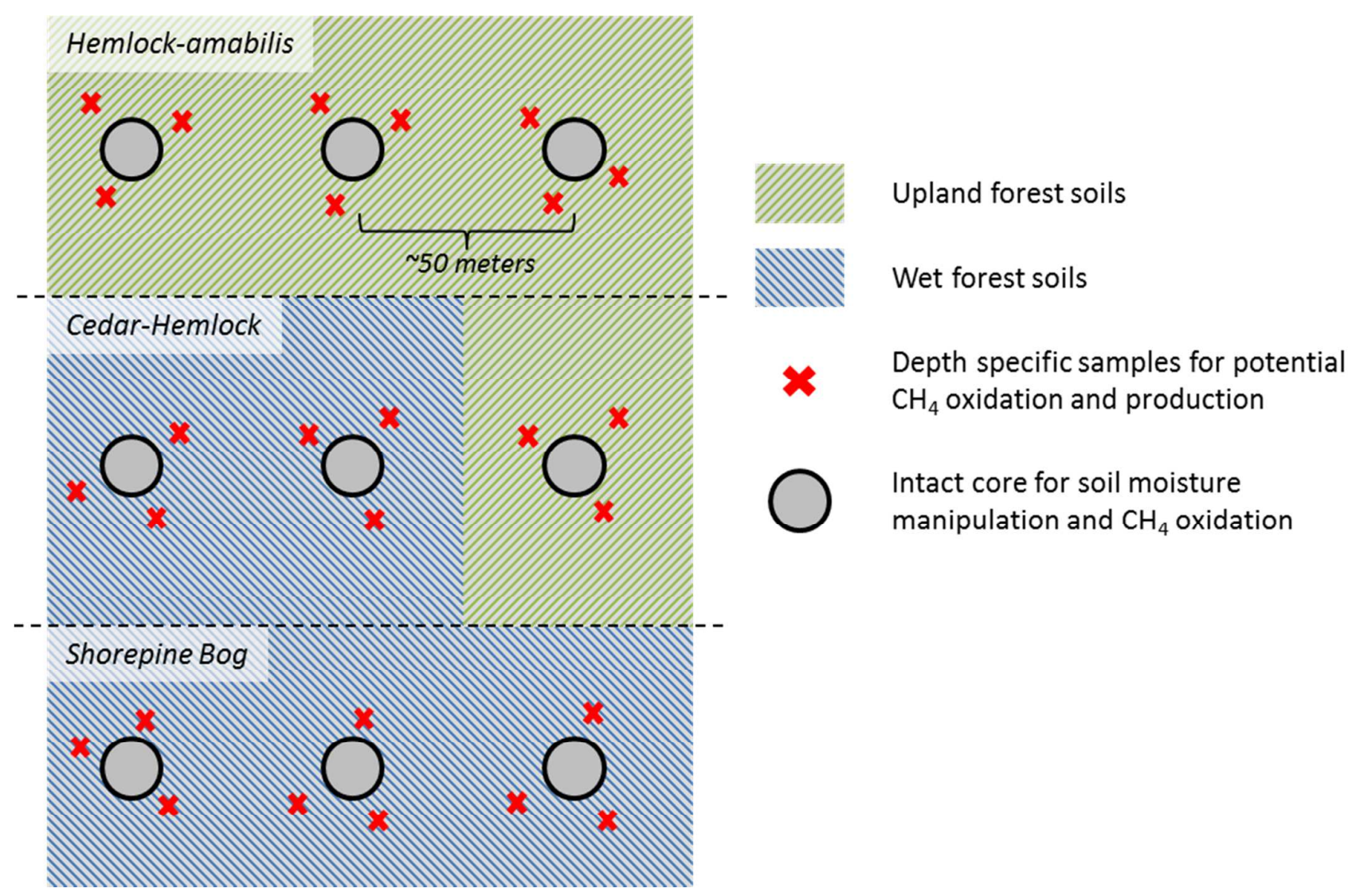

Fig. S1 Schematic illustration of the soil sampling layout at the Beaver Lake site. In each forest type three sub-plot distanced at least 50 meters were subjected to soil sampling for both potential net $\mathrm{CH} 4$ oxidation and production experiments and the response of $\mathrm{CH} 4$ oxidation to changes in soil moisture. 
Linear decrease in headspace $\mathrm{CH}_{4}$ concentrations in potential net high- and low affinity experiment

High affinity $\mathrm{CH}_{4}$ oxidation experiment
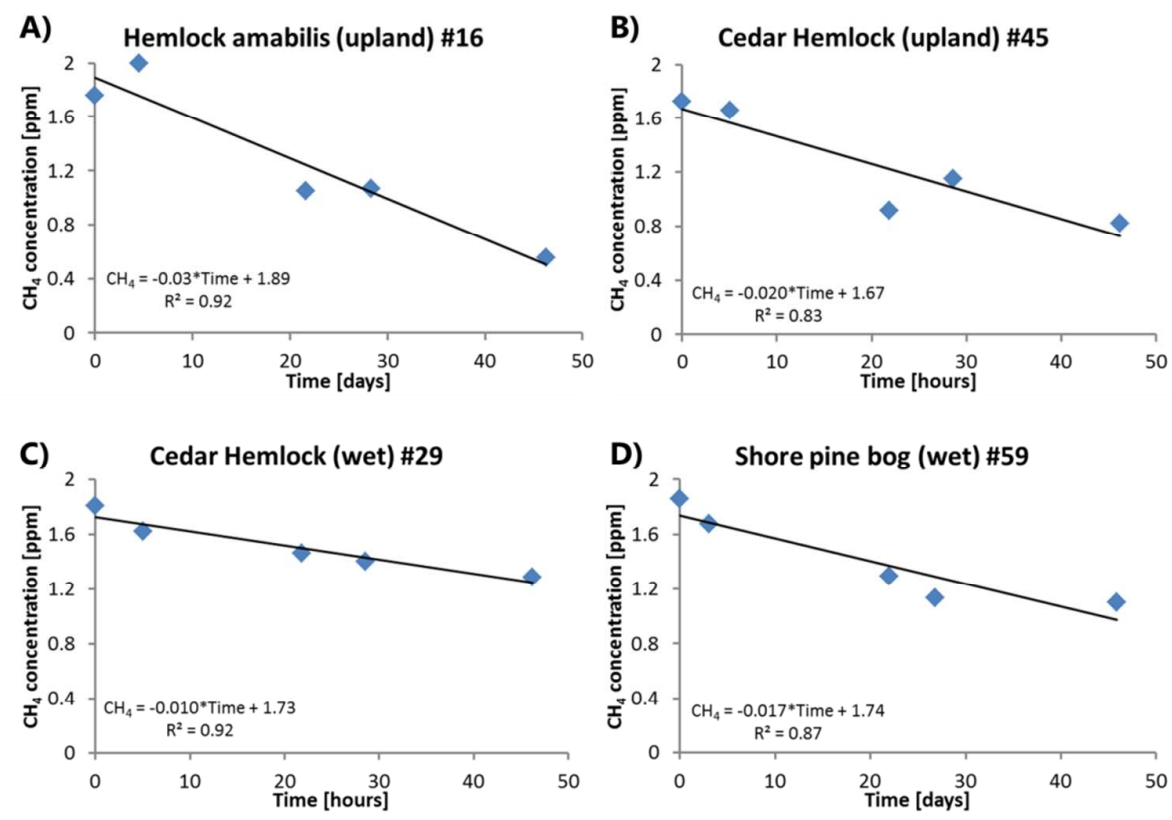

Figure S2 Representative examples of the linear decrease of $\mathrm{CH} 4$ concentrations in the high-affinity net $\mathrm{CH}_{4}$ oxidation experiment for upland soils A) Hemlock-amabilis and B) Cedar-Hemlock (upland) and wet forest soils C) Cedar-Hemlock and D) Shore pine Bog. Linear regression is indicated by the black line and regression equation. The regression for the Shore pine Bog was performed for the first three data points.

\section{Low affinity $\mathrm{CH}_{4}$ oxidation experiment}
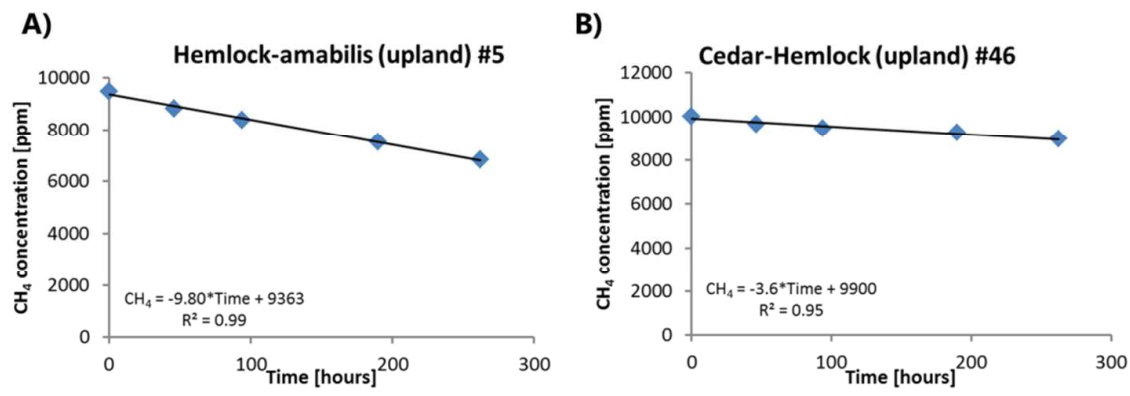

C)

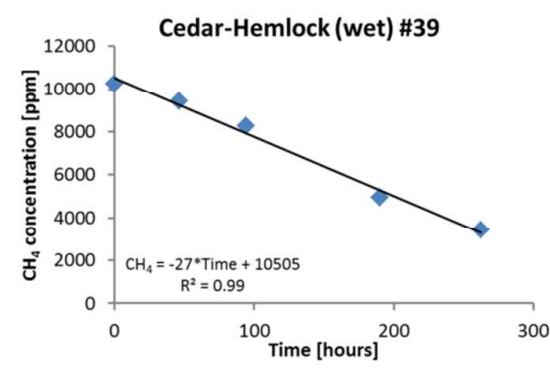

D)

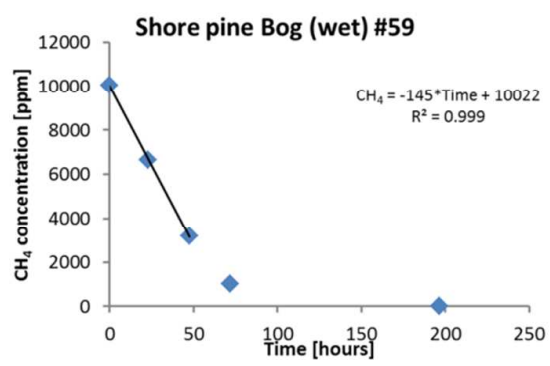

Figure S3 Representative examples of the linear decrease of $\mathrm{CH} 4$ concentrations in the low-affinity net $\mathrm{CH} 4$ oxidation experiment for upland soils A) Hemlock-amabilis and B) Cedar-Hemlock (upland) and wet forest soils C) Cedar-Hemlock and D) Shore pine Bog. Linear regression is indicated by the black line and regression equation. The regression for the Shore pine Bog was performed for the first three data points. 


\section{Logistic equation to calculate $\mathrm{CH}_{4}$ production}

Calculation of potential $\mathrm{CH}_{4}$ production rates were based on logistic regression. We observed a pronounced behavior of $\mathrm{CH}_{4}$ concentrations in incubation bottles that resembled logistic growth known from population biology.

\section{Observed $\mathrm{CH}_{4}$ concentration}

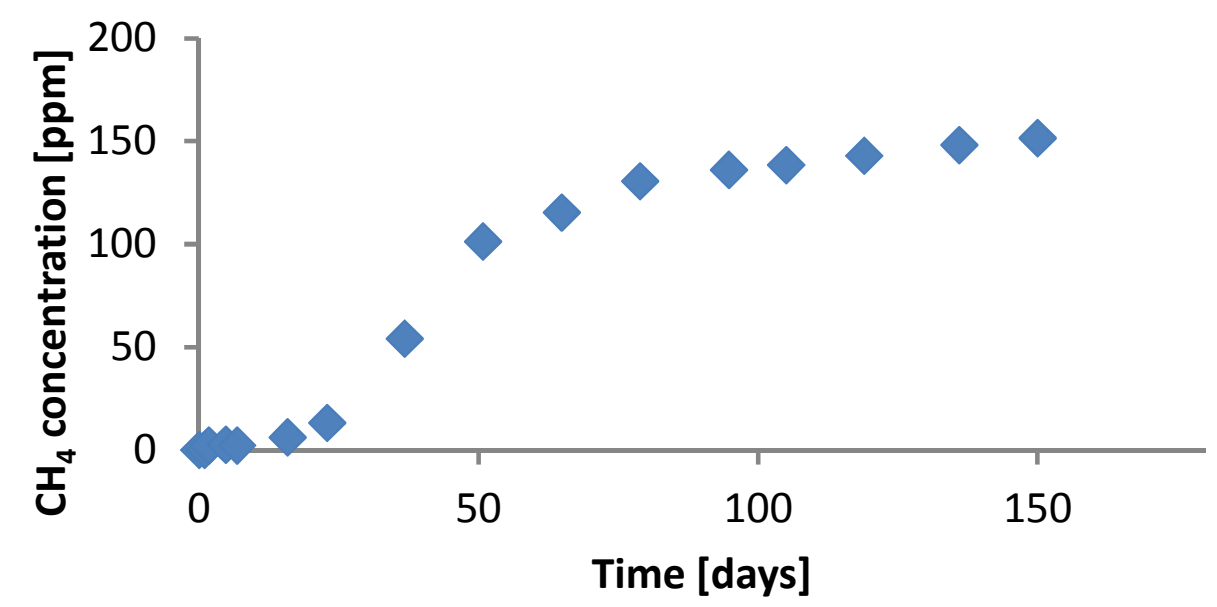

Fig. S4 Example of observed $\mathrm{CH}_{4}$ concentration [ppmv] in an incubation bottle over app. 160 days of incubation

We used the following logistic equation to fit a curve through observed $\mathrm{CH}_{4}$ concentrations over time:

$$
C(t)=\frac{L}{1+C \mathrm{e}^{-k t}}
$$

Where $\mathrm{C}(\mathrm{t})$ is the $\mathrm{CH}_{4}$ concentration at time $\mathrm{t}$ and $\mathrm{L}, \mathrm{C}$ and $\mathrm{k}$ are parameters. The 1 . derivative of $(\mathrm{S} 1)$ or rate of concentration change with time is given by:

$$
\begin{aligned}
& \frac{d C}{d t}=L \frac{k C e^{k t}}{\left(e^{k t}+C\right)^{2}} \\
& t_{\max }=\frac{\ln (C)}{k}
\end{aligned}
$$

The rate of maximum $\mathrm{CH}_{4}$ production at $\mathrm{t}_{\max }$ can be found by inserting (S3) in to (S2), giving the following simple equation to estimate the maximum rate of $\mathrm{CH}_{4}$ production at $\mathrm{t}_{\max }$ :

$$
S_{C_{4}, \max }=L \frac{k}{4}
$$

\section{Exponential equation for calculation of $\mathrm{CH}_{4}$ and $\mathrm{CO}_{2}$ fluxes in the soil moisture response experiments}

The $\mathrm{CH}_{4}$ and $\mathrm{CO}_{2}$ fluxes displayed a non-linear behavior as observed in closed chamber systems. 


\section{Non-linear flux calculation}

We used the Hutchinson-Mosier model (Hutchinson and Mosier, 1981) for calculating the flux from nonlinear data was (Pihlatie et al., 2013).

The concentration of $\mathrm{CO}_{2}$ and $\mathrm{CH}_{4}$ in the closed system was described according to Eq. S5:

$$
C(t)=C_{\infty}+\left(C_{0}-C_{\infty}\right) e^{-\kappa t} \quad(\text { Eq. S5) }
$$

Where $\mathrm{C}_{0}$ is the headspace concentration ( $\mathrm{ppb}$ ) at $\mathrm{t}=0$ and $\mathrm{C}_{\infty}$ is the assumed constant concentration source at a depth $Z(m)$ in $p p b, \kappa$ is the concentration saturation rate $\left(s^{-1}\right)$

The flux (ppb s-1) at time zero was calculated according to Eq. S6:

$$
S_{\text {exp }}=\left(C_{\infty}-C_{0}\right) * \kappa
$$

The flux at $\mathrm{t}_{\max }\left(\mathrm{CH}_{4}\right.$ production, Eq. S4) or $\mathrm{t}=0\left(\mathrm{CO}_{2}\right.$ production or $\mathrm{CH}_{4}$ consumption, Eq. $\left.\mathrm{S} 6\right)$ was converted to $\mathrm{nmol} \mathrm{CH}_{4} \mathrm{~d}^{-1}$ by inserting $\mathrm{S}_{\text {exp }}$ in Eq. S7:

$$
F_{0}=S \frac{V}{R *(273.15+T)} * 3600 * 24 \quad \text { (Eq. S7) }
$$

Where $S_{\text {exp }}$ is the flux $\left(p p b s^{-1}\right.$ ) at $t=0, V$ is the volume of the closed system $(L), R$ is the gas constant $\left(L^{-1}\right.$ $\left.\mathrm{mol}^{-1}\right)$ and $\mathrm{T}$ is the incubation temperature $\left({ }^{\circ} \mathrm{C}\right)$.

\section{References}

Hutchinson, G.L., Mosier, A.R., 1981. Improved Soil Cover Method for Field Measurement of Nitrous Oxide Fluxes. Soil Science Society of America Journal 45, 311. doi:10.2136/sssaj1981.03615995004500020017x

Pihlatie, M.K., Christiansen, J.R., Aaltonen, H., Korhonen, J.F.J., Nordbo, A., Rasilo, T., Benanti, G., Giebels, M., Helmy, M., Sheehy, J., Jones, S., Juszczak, R., Klefoth, R., Lobo-do-Vale, R., Rosa, A.P., Schreiber, P., Serça, D., Vicca, S., Wolf, B., Pumpanen, J., 2013. Comparison of static chambers to measure $\mathrm{CH} 4$ emissions from soils. Agricultural and Forest Meteorology 171-172, 124-136. doi:10.1016/j.agrformet.2012.11.008 